\title{
Psychophysical estimation of acid intensity and determination of sweet-acid interaction in a fish paste containing glycerol
}

\author{
Estimação psicofísica da intensidade ácida e determinação da \\ interação ácido-doce em patê de pescado contendo glicerol
}

\author{
Gabriela Leonor Sánchez PASCUA ${ }^{1}$, Maria Rosa CASALES ${ }^{2,3}$, Maria Isabel YEANNES ${ }^{2,3,4 *}$
}

\begin{abstract}
In a fish paste made with cooked Brazilian flathead (Percophis brasiliensis), glycerol (17\%), sodium chloride (1.5\%) and potassium sorbate $(0.1 \%)$ the following acid percentages: $0.2 ; 0.4 ; 0.6 ; 0.8,1$ and $1.5 \% \mathrm{w} / \mathrm{w}$ were incorporated to determine the relationship between added acetic acid and the sensorially perceived intensity, and the effects of the combination of sweet-acid tastes. Tests for paired comparison, ranking and structured verbal scales for sweet and acid attributes and psychophysical test were carried out. There was a perceptible difference among samples for differences of 0.4 units of acid concentration. Samples indicated as sweeter by $89.47 \%$ of the judges were those containing a lesser acid concentration. A reduction in glycerol sweetness when increasing acid levels was observed. Acetic acid reduced the sweetness of glycerol and inversely glycerol reduced the acidity of acetic acid. The data obtained with the magnitude estimation test agree with Steven's law. Keywords: fish products; intermediate moisture; sensorial tests; taste interactions.
\end{abstract}

\section{Resumo}

Foram incorporados glicerol (17\%), cloreto de sódio (1,5\%) e sorbato de potássio ( $0.1 \%)$ nas seguintes porcentagens de ácido: 0,2; 0,4; 0,6; 0,8; 1 e 1,5\% p/p, em um patê elaborado a partir de congro-real (Percophis brasiliensis) cozido, com o intuito de determinar a relação entre o ácido acético adicionado e a intensidade sensorialmente percebida, assim como o efeito da combinação dos gostos doce e ácido. Foram realizados testes de comparação pareada, de classificação e também estruturada uma escala verbal para os atributos ácido e doce, e testes psicofísicos. Foi percebida diferença entre as amostras com diferença de 0,4 unidades de concentração de ácido. As amostras indicadas como as mais doces por $89,47 \%$ dos julgadores foram as que continham menor concentração de ácido. Foi observada a redução da doçura do glicerol quando aumentaram os níveis de ácido. O ácido acético reduziu a doçura do glicerol e, inversamente, o glicerol reduziu a acidez do ácido acético. Os dados obtidos com o teste de estimação de magnitude concordaram com a lei de Steven.

Palavras-chave: produtos de peixes; umidade intermediária; testes sensoriais; interação dos gostos.

\section{Introduction}

This work analyzed from sensorial point of view the development of a fish product using combined process or Hurdle Technology. The fish species chose was Brazilian flathead (Percophis brasiliensis) and the product an intermediate moisture fish paste.

Brazilian flathead is a species of fish from coastal and benthic habitats. Its distribution ranges from the latitude of Rio de Janeiro in Brazil to 47'S in Argentina. The size of the resource in Argentina is moderate, being underexploited (CFP, 1998). It is used for export as frozen skinless fillets and fresh for the domestic market. It is one of the species open to increased catches without going into over-fishing and is susceptible to greater added value and different presentation (COUSSEAU; PERROTTA, 2000).

In order to obtain sterility and stability without using severe thermal treatment the fish paste was designed to obtain $\mathrm{a}_{\mathrm{w}}$ values lower than 0.92 and $\mathrm{pH}$ lower than 6.2. Moreover, fillets were cooked in order to promote enzymatic inactivation, and potassium sorbate was added as antimycotic agent. For the decrease in $\mathrm{a}_{\mathrm{w}}$, sodium chloride and glycerol were used. To increase microbiological stability, a weak organic acid was added taking into account its behavior in food (GARDENER, 1966; MULTON, 1988; LÜCK, 1977; MURRAY et al. 1997; GUERRERO, 1993). Weak organic acid promotes modifications in sensorial characteristics; consequently, considering the modification of taste, it is important to select the appropriate acid for this type of product (GARDENER, 1966; LÜCK, 1977; MULTON, 1988; FISHER; SCOTT, 2000). Acetic acid was selected for this fish paste due to its consumer acceptance, recorded in previous works on fishing products (MULTON, 1988; YEANNES; CASALES, 1995), but is important to note that at certain concentrations acetic acid can be aggressive (FISHER; SCOTT, 2000). Glycerol affects texture and taste: it has a plastifying effect on the texture

Recebido para publicação em 25/8/2008

Aceito para publicação em 8/7/2009 (003799)

${ }^{1}$ Comisión de Investigaciones Científicas de la Prov. de Buenos Aires, Grupo de Investigación Preservación y Calidad de Alimentos, Universidad Nacional Mar del Plata Buenos Aires, Argentina

2 Consejo Nacional de Investigaciones Científicas y Técnicas, Grupo de Investigación Preservación y Calidad de Alimentos, Universidad Nacional Mar del Plata, Buenos Aires, Argentina 3 Grupo de Investigación Preservación y Calidad de Alimentos, Departamento de Química y Alimentos, Facultad de Ingeniería, Universidad Nacional de Mar del Plata. J. B. Justo 4302, 7600 Mar del Plata, Provincia de Buenos Aires, Argentina, E-mail: myeannes@mdp.edu.ar

4 Universidad Católica Argentina, Facultad de Ciencias Agrarias, Buenos Aires Argentina

${ }^{*}$ A quem a correspondência deve ser enviada 
(MULTON, 1988; SÁNCHEZ PASCUA et al., 1994 a; SÁNCHEZ PASCUA et al., 1994b) and in certain concentrations, it has a bitter or sweet taste, so it needs to be considered that some residual taste could appear (JAYARAMAN; DAS GUPTA, 1978; MULTON, 1988, SÁNCHEZ PASCUA et al., 1994a). For this reason, the concentrations of substances used in this work are limited by the consumer acceptance, and their combination offers an interaction of stimuli which may produce enhancement, synergy, suppression and/or residual tastes.

The sweet-acid combination has been studied from the sensorial point of view in solutions, fruits, fruit juices and fruit pulps (PANGBORN; CHRIP, 1964; PANGBORN; TRABUE, 1964; SCHIFFERSTEIN; FRIJTERS, 1990; BONNANS; NOBLE, 1993; MARSH et al., 2003; MARSH et al., 2006). These authors determined that sweet/acid combination exhibited a mutual masking effect; it was demonstrated that citric acid suppresses the sweetness of sucrose and that, inversely, sucrose suppresses the sourness of citric acid. In fish products the sweet-acid combination has been used, such as fish marinated with acetic acid and sugar (MCLAY, 1972; MEYER, 1965), Casales and Yeannes (2006) used acetic acid and sorbitol in anchovy marinating, where sorbitol provide sweet taste. These products were pleasant from the sensorial point of view but no studies of sweet-acid interaction were undertaken.

Taking into consideration the abovementioned, the objectives of the present work were to determine the relationship between added acetic acid and the sensorially perceived intensity, and the effects of the sweet-acid combination taste on an intermediate moisture fish paste using glycerol as humectant.

\section{Materials and methods}

\subsection{Intermediate moisture fish paste}

Fillets of Brazilian flathead (Percophis brasiliensis) were cooked and minced to use in a fish paste, incorporating $17 \%$ of glycerol, $1.5 \%$ of sodium chloride and $0.1 \%$ of potassium sorbate (SÁNCHEZ PASCUA et al., 1994b). At the same time, different concentrations of acetic acid were added. This process is shown in Figure 1 and the physico-chemical characteristics of the intermediate moisture fish paste without acid are presented in Table 1.

To determine the maximum sensorially accepted acidity, the results of acetic acid content in the fillet of anchovy (Engraulis anchoita) obtained by Yeannes and Casales (1995) in marinated process were taken into account. According to the aforementioned, the amount of acetic acid added to the fish paste was: $0.2 ; 0.4 ; 0.6 ; 0.8 ; 1.0$ and $1.5 \% \mathrm{w} / \mathrm{w}$.

\subsection{Chemical and physical analyses}

Determinations of $\mathrm{pH}$ were carried out on raw material, on fish paste prior to the incorporation of acid and on fish pastes with different acid contents. The $\mathrm{pH}$ was measured by a $\mathrm{pH}$-meter with a glass electrode (Parsec model Vega IV) in a homogenate 1:1 of $10 \mathrm{~g}$ of sample and water according to AOAC Sec. 981.12 (1990). In the base paste, the $\mathrm{a}_{\mathrm{w}}$ was gravimetrically determined (SÁNCHEZ PASCUA et al., 1994a). Water content

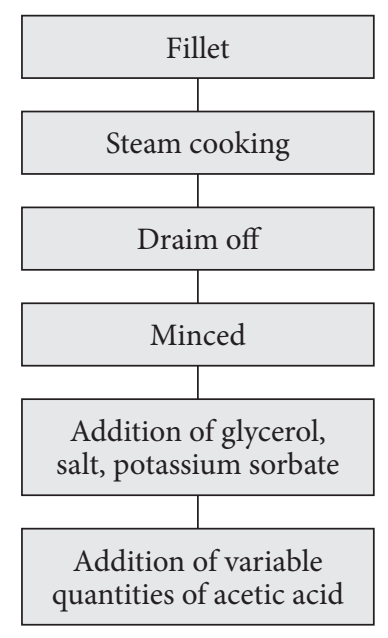

Figure 1. Process of elaboration of the fish paste.

Table 1. Physico-chemical characteristics of the fish paste without acid.

\begin{tabular}{ccccccc}
\hline Sample & $\begin{array}{c}\text { Water } \\
\text { content } \\
\text { g.100 g-1 }\end{array}$ & $\begin{array}{c}\text { Lipids } \\
\text { g. } 100 \mathrm{~g}^{-1}\end{array}$ & $\begin{array}{c}\mathrm{ClNa} \\
\text { g. } 100 \mathrm{~g}^{-1}\end{array}$ & $\begin{array}{c}\text { Glycerol } \\
\text { g.100 g }\end{array}$ & $\mathrm{pH}$ & $\mathrm{a}_{\mathrm{w}}$ \\
\hline $\begin{array}{c}\text { Fish paste } \\
\text { without acid }\end{array}$ & 58.02 & 2.29 & 1.5 & 17 & 6.8 & 0.915 \\
\hline
\end{tabular}

was determined drying $5 \mathrm{~g}$ of sample in an oven with a sulfuric acid atmosphere (FAVETTO et al., 1979).

Lipids were determined using the acid hydrolysis method. The results were expressed as g. $100 \mathrm{~g}^{-1}$ of paste according to AOAC Sec. 922.06 (1990).

\subsection{Sensorial evaluation}

The sensorial tests were carried out by six trained panelists and selected by their ability in recognizing basic tastes. They were trained by means of matching, detection, discrimination and ranking tests to determine the ability to discriminate levels of intensity of basic tastes (sweet, sour, bitter, salty, umami) (MEILGAARD et al. 1996; IRAM 1996). Taking into account the characteristics of this product the sweet taste provided by glycerol at used concentrations and acid taste provided by acetic acid were assessed.

The questionnaires for each test were designed according to standardized patterns (PEDRERO; PANGBORN, 1989; ANZALDÚA MORALES, 1994, MEILGAARD et al. 1996), and samples were always presented in the same way. This uniformity included portion quantity, temperature $\left(21 \pm 1{ }^{\circ} \mathrm{C}\right.$.), recipients and utensils. A table of aleatory numbers was used to codify the samples (ICMSF, 1981).

\subsection{Test sequence}

The following sequence of tests was carried out: Difference Tests (paired comparison test), Ranking Test, Scaling Test (using structured verbal scales), and for acid attribute, a Psychophysical Test (magnitude estimation) was chosen. 


\section{Paired comparison test}

The Paired Comparison test was used by comparing perceptible differences in sweet and acid tastes among samples. To check if the judges could perceive differences in sweet and acid tastes, pairs of samples with $17 \%$ glycerol and the following acid concentration were tested: 0.4 versus $0.8 \%$ and 0.6 versus $1 \%$.

\section{Ranking test}

Subsequently, the Ranking Test was used to grade samples from lower to higher values, according to the intensity levels perceived for both sweetness and acidity. Four samples in random order with $17 \%$ glycerol and with different acid concentration (from 0.2 to $1.5 \%$ ) were evaluated in each test.

\section{Verbal structured scale}

Verbal structured scales with six intervals were used to qualify the perceived intensity for both acid and sweet tastes, with the extremes of each scale being nothing, and extremely acid/sweet. Samples with constant glycerol concentration (17\%) and acid concentration variable were used (from 0.2 to $1 \%$ ) Four samples indicating the testing order were assessed in each session.

\section{Magnitude estimation}

In order to estimate the magnitude of perceptible differences in the acid taste and to determine the possible sweet-acid interaction, a psychophysical method was applied assigning a value to the intensity perceived. The tasting order was indicated beforehand. For this test four codified samples were evaluated in each session. An arbitrary value was assigned to the first sample (reference sample) so that panelists could assign the other samples, a superior or inferior value in relation to that of the reference, and according to the intensity of the perceived acid taste. This test was used in pastes with $17 \%$ glycerol and different percentages of acid, and in pastes containing only acid in the same percentages.

With this sequence of tests the sweet-acid interaction and its effect on the taste of the product were determined.

\section{Results and discussion}

The characteristics of the paste without acid and the $\mathrm{pH}$ of pastes with different percentages of acid are shown in Tables 1 and 2.

The results of paired comparison tests showed that significant perceptible differences $(\mathrm{p}<0.001)$ existed among samples with changes in acid concentration of 0.4 units. As much as $89.47 \%$ of panelists indicated those samples containing a less acid concentration as sweeter.

In the ranking test the acid content was correctly ordered by $95 \%$ of the judges and for the sweet taste $83.3 \%$ of the judges also ordered the samples, although glycerol concentration remained constant. The sample with the lowest acid content was perceived as sweeter. The aforementioned would indicate a modification in the perception of sweetness of glycerol by increasing acid levels. These results agree with those obtained by Pangborn and Chrip (1964); Pangborn and Trabue (1964); Schifferstein and Frijters (1990); Bonnans and Noble (1993); Marsh et al. (2003); Marsh et al. (2006) in fruits, fruit juices and fruit pulps containing citric acid and sucrose, showing the lack of this type of information in fish products.

Sweet and acid tastes perceived in fish pastes with different acid concentration are shown in Figure 2. The results obtained with structured scales indicated that samples with $1 \%$ acid were significantly more acid $(\mathrm{p}<0.01)$ than the rest, and those with $0.8 \%$ concentration were significantly different $(\mathrm{p}<0.01)$ from samples with 0.2 and $0.4 \%$ acid concentration. No differences in acid perception were detected among the following sample couples: 0.8 and $0.6 \% ; 0.6$ and $0.4 \% ; 0.6$ and $0.2 \%$, and 0.2 and $0.4 \%$ acid concentrations. The fact that the sample with $0.2 \%$ concentration significantly differed $(p<0.01)$ from the rest was determined in the sweet taste evaluation. Significant differences between 0.6 and $0.4 \% ; 0.8$ and $0.4 \% ; 0.6$ and $1 \%$, and 0.8 and $1 \%$ acid concentration were determined, but no differences between 0.6 and $0.8 \%$ acid concentration were detected.

Steven's law was used to obtain relationships between the perceived sensation (S) and the variations in the concentration of the stimulus (C) (GUIRAO, 1980; BARBIERI et al. 1999; FISHER; SCOTT, 2000) (Equation 1):

$\log \mathrm{S}=\log \mathrm{K}+\mathrm{n} \log \mathrm{C}$

S being, sensorial perception; $\mathrm{K}$, constant; C, concentration of the stimulus (acid); n, exponent of Steven's law.

Table 2. $\mathrm{pH}$ values of fish pastes with different concentrations of acid.

\begin{tabular}{ccccccc}
\hline $\begin{array}{c}\text { Acid } \\
\text { g. } 100 \mathrm{~g}^{-1}\end{array}$ & $0.2 \%$ & $0.4 \%$ & $0.6 \%$ & $0.8 \%$ & $1 \%$ & $1.5 \%$ \\
\hline $\mathrm{pH}$ & 6.1 & 5.8 & 5.5 & 5.25 & 5 & 4.7 \\
\hline
\end{tabular}

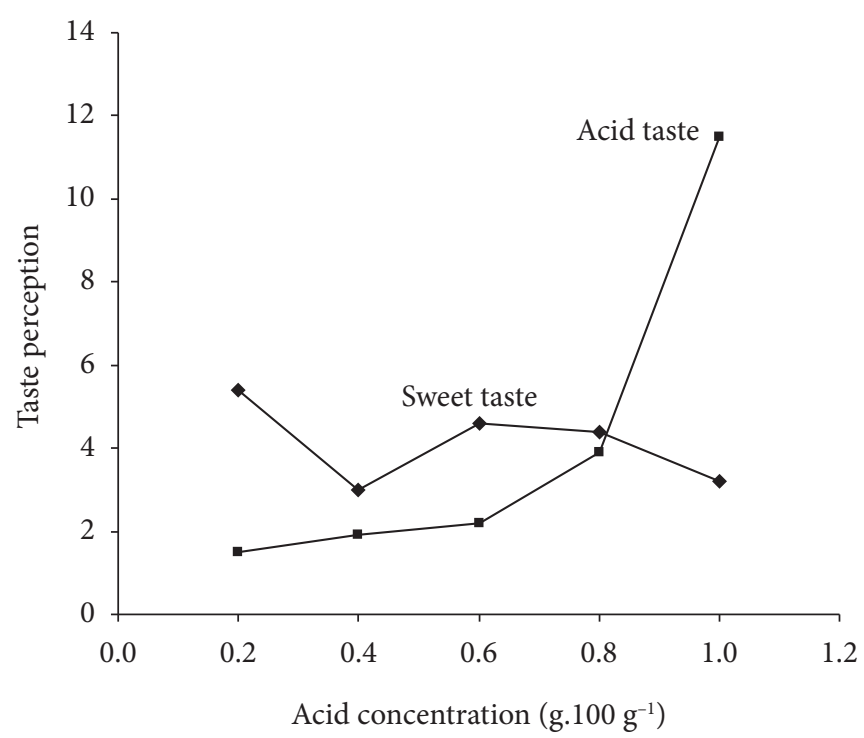

Figure 2. Sensorial perception of sweet and acid tastes from verbal structured scales in samples with constant glycerol concentration and variable acid concentration. 
Fish Paste without glycerol (Equation 2):

$\log \mathrm{S}=1.752 \times \log \mathrm{C}_{\text {acid }}+1.154(\mathrm{r}=0.958)$

Fish Paste with $17 \%$ of glycerol with different concentrations of acid (Equation 3):

$\log \mathrm{S}=1.208 \times \log \mathrm{C}_{\text {acid }}+1.167(\mathrm{r}=0.912)$

The values of coefficients in Equations 2 and 3 are higher than the unit and they agree with those obtained by several authors for other gustatory stimulus (GUIRAO, 1980). The coefficient of the equation for the fish paste without glycerol was higher than the fish paste with $17 \%$ glycerol which would indicate that the sweet taste of the glycerol diminished the intensity of the acid stimulus. The higher correlation coefficient in Equation 2 indicates that panelists proceed to a much easier discrimination when the influence of the sweet taste is not present.

\section{Conclusions}

The combination glycerol-acetic acid exhibited a mutual reduction effect on perception of sweet and acid tastes. This subject has not been analyzed until now in fish products from this point of view.

The high correlation coefficient obtained with Steven's equation indicates that functionality exists between the psychophysical magnitude of the acid taste and the physical concentration.

\section{Acknowledgements}

This work was financed by the Universidad Nacional de Mar del Plata (UNMDP). The authors wish to thank to this Institution. The authors are grateful to Prof. Ana Prisco for corrections to the English of the manuscript.

\section{References}

ANZALDÚA-MORALES, A. La evaluación sensorial de los alimentos en la teoría y la práctica. Zaragoza: Ed. Acribia, 1994.

ASSOCIATION OF OFFICIAL ANALYTICAL CHEMISTS - AOAC. Official methods of analysis. $15 \mathrm{ed}$. Washington, 1990

BARBIERI, T.; HOUGH, G.; IGLESIAS, H. Análisis sensorial de semillas de mostaza. In: ALMEIDA, T. C. A. et al. (Eds.). Avances en análisis sensorial. São Paulo: Varela, 1999.

BONNANS, S.; NOBLE, A. C. Effect of sweetener type and of sweetener and acid levels on temporal perception of sweetness, sourness and fruitiness. Chemical Senses, v. 18, n. 3, p. 273-283, 1993.

CASALES, M. R.; YEANNES, M. I. Análisis de difusión múltiple y de equilibrio en el proceso de marinación de anchoita (Engraulis anchoita). In: CONGRESO ARGENTINO DE CIENCIA Y TECNOLOGÍA DE ALIMENTOS Y PRIMER SIMPOSIO INTERNACIONAL DE NUEVAS TECNOLOGÍAS. Mar del Plata: Libro de Actas, 2006. p. 1217-1224. (v. 4)

CONSEJO FEDERAL PESQUERO - CFP. Resolución n. 11, de 22 de Diciembre de 1998. Captura Máxima Permitida de Pez Palo. Boletín Oficial, Argentina. 5 de Enero de 1999.

COUSSEAU, M. B.; PERROTTA, R. G. Peces marinos de Argentina: biología, distribución, pesca. Mar del Plata: Instituto Nacional de Investigación y Desarrollo Pesquero, 2000.
FAVETTO G.; CHIRIFE, J.; BARTHOLOMAI, G. B. Determination of moisture content in glycerol containing intermediate moisture foods. Journal of Food Science, v. 44, n. 4, p. 1258-1259, 1979.

FISHER, C.; SCOTT, T. Flavores de los alimentos: biología y química. Zaragoza: Ed. Acribia, 2000

GARDENER, H. Food acidulants: allied chemical corporation. New York: Allied Chemical, 1966.

GUERRERO, S. Desarrollo de una tecnología de factores combinados para preservar puré de bananas de alta humedad. 1993. p. 484. Tese (Doutorado) - Universidad de Buenos Aires - UBA, Buenos Aires.

GUIRAO, M. Los sentidos: bases de la percepción. España: Ed. Alambra, 1980.

INTERNATIONAL COMMISSION ON MICROBIOLOGICAL SPECIFICATIONS FOR FOODS - ICMSF. Microorganismos de los alimentos. Zaragoza: Ed. Acribia, 1981. (v. 2)

INSTITUTO ARGENTINO DE NORMALIZACIÓN Y CERTIFICACIÓN - IRAM. NORMA 20004. Argentina, 1996.

JAYARAMAN, K. S.; DAS GUPTA, D. K. Development and storage stability of intermediate moisture carrot. Journal of Food Science, v. 43, n. 2, p. 1880-1881, 1978.

LÜCK, E. Conservación química de los alimentos. Zaragoza: Ed. Acribia, 1977.

MARSH, K. et al. The use of fruit pulps to explore flavour in kiwifruit. ISHS Act Horticulturae, n. 610, p. 229-237, 2003.

MARSH, K. et al. Perception of flavour in standardised fruit pulps with addition of acids or sugars. Food Quality and Preferences, v. 17, n. 5, p. 376-386, 2006.

MCLAY, R. Marinades. Aberdeen, Scotland: Ministry of Agriculture, 1972. (Torry Advisore Note, 56)

MEILGAARD, M.; CIVILLE, G.; CARR, B. Sensory evaluation techniques. 2 ed. London: CRC Press, 1996.

MEYER, V. Marinades. In: BORGSTROM, G. (Ed.). Fish as Food. New York: Academic Press, 1965. p. 165-193. (part 1, v. 3)

MULTON, J. L. Aditivos y auxiliares de fabricación en las industrias agroalimentarias. Zaragoza: Ed. Acribia, 1988.

MURRAY, R. et al. Bioquímica de Harper. México: Editorial el Manual Moderno, 1997.

PANGBORN, R. M.; CHRIP, R. B. Taste Interrelationships: V. Sucrose, sodium chloride, and citric acid in lima bean purée. Journal of Food Science, v. 29, n. 2, p. 123-240, 1964.

PANGBORN, M. R.; TRABUE, J. M. Taste Interrelationships: VI. Sucrose, sodium chloride, and citric acid in canned tomato juice. Journal of Food Science, v. 29, n. 4, p. 379-524, 1964.

PEDRERO, D. L.; PANGBORN, R. M. Evaluación sensorial de los alimentos. métodos analíticos. México: Ed. Alhambra, 1989.

SÁNCHEZ-PASCUA, G. L.; CASALES, M. R.; YEANNES, M. I. Preliminary development of Intermediate moisture, pasteurised mackerel (Scomber japonicus marplatensis) chunks. Journal of Science of Food and Agriculture, v. 64, n. 2, p. 199-204, 1994a.

SÁNCHEZ-PASCUA, G. L.; CASALES, M. R.; YEANNES, M. I. Utilización del método de mezcla directa para la formulación de pasta de caballa (Scomber japonicus marplatensis). In: CONGRESO ARGENTINO DE CIENCIA Y TECNOLOGÍA DE ALIMENTOS Y PRIMER ENCUENTRO DE TÉCNICOS DE ALIMENTOS DEL CONO SUR, 6, 1994, Buenos Aires. Buenos Aires: Libro de Actas, 1994b. p. 341-343.

SCHIFFERSTEIN, H. N. J.; FRIJTERS, J. E. R. Sensory integration in citric acid/sucrose mixtures. Chemical Senses, v. 15, n. 1, p. 87-109, 1990.

YEANNES, M. I.; CASALES, M. R. Estudio de las variables de proceso de marinados de anchoíta (Engraulis anchoita). Alimentaria, Revista de Tecnología e Higiene de los Alimentos, v. 262, n. 1, p. 87-91, 1995. 